\title{
RESEARCH CO-OPERATIVE COMMITTEE
}

$\mathrm{T}$

HE OFFICERS of the ten Research Sub-Committees have been asked recently to commence to collect the data from the various committee members, for the compilation of their annual reports.

It may be of interest to the members of the Society to learn who are presently responsible for the activities of the committee, and to, review its aims and objectives.

\section{Executive}

F. D. Mulholland, Chairman; A. R. Fenwick, Secretary; Prof. F. M. Knapp, B.C. Forest School, University of British Columbia; E. C. Manning, Chief Forester, British Columbia; Dr. C. D. Howe, Dean, Faculty of Forestry, University of Toronto; Howard Kennedy, Quebec Forest Industries Association, Quebec, P.Q.; L. R. Seheult, Singer Mfg. Co., Singer, P.Q.; and the Chairman and Secretary of each sub-committee.

\section{Sub-Committees}

Silviculture-Chairman, W. M. Robertson; Secretary, E. Bonner. Entomology-Chairman, W. A. E. Pepler; Secretary, G. A. Mulloy. Pathology-Chairman, J. R. Dickson; Secretary, A. J. Skolko.

Surveys-Chairman, F. R. Wilcox; Secretary, I. Fogh.

Utilization-Chairman, T. A. McElhanney; Secretary, E. S. Fellows.

Reforestation-Chairman, A. H. Richardson; Secretary, D. I. Crossley.

Farm Woodlots-Chairman, I. C. Marritt; Secretary, K. B. Brown.

Education-Chairman, J. M. Gibson; Secretary, R. C. Hosie.

Woods Operation-Chairman, W. Kishbaugh; Secretary, C. W. R. Day.

Forest Fire-Chairman, P. McEwen; Secretary, J. G. Wright.

The responsibility for the naming of the personnel of each sub-committee rests with the Chairman, and the intention is that each section of the Dominion be represented on each sub-committee.

The objectives of the Research Cooperative Committee, as stated at the time of organization some years ago, are:-

1. To provide a means of acquainting all those interested as to the research work that has been, or is being conducted.

2. To provide those conducting research projects with information as to the problems which require study.

3. To secure the co-operation of research officers and forest industries in carrying out research, and in the practical application of the findings in forest management.

4. To determine the best means of conducting the various research projects.

5. To establish personal contacts between men engaged in forest research and those in whose interests they are working.

The annual reports of the various sub-committees are usually summarized for presentation at the Annual Meeting, and for publication in the Chronicle and Bulletin. Full-length reports are, however, available to any members upon request to the Secretary. 